\title{
Small Business Funding Mechanisms
}

National Cancer Institute

\section{Source}

National Cancer Institute. Small Business Funding Mechanisms. NCI Thesaurus. Code C19197.

Government-wide programs to promote technology transfer. 